УдК 347.1

DOI https://doi.org/10.51989/NUL.2021.4.4

\title{
ЩОДО ОКРЕМИХ ПОЛОЖЕНЬ КОНЦЕПЦІЇ ОНОВЛЕННЯ ЦИВІЛЬНОГО КОДЕКСУ УКРАЇНИ
}

\section{Зуб Ігор Володимирович,}

кандидат юридичних наук, провідний науковий співробітник відділу дослідження проблем взаємодії держави та громадського суспільства Київського регіонального центру Національної академії правових наук України

У статті здійснюється аналіз окремих положень Концепції оновлення Цивільного кодексу України. Насамперед йдеться про підтримку пропозиції про скасування Господарського кодексу України. Водночас висловлено ідею про можливість прийняття поряд з оновленим Цивільним кодексом України (як кодексу приватного права) кодифікованого законодавчого акту, в якому були б систематизовані питання державного регулювання господарською діяльністю (реєстрація юридичних осіб, ліцензування, дозвільна діяльність, контроль тощо).

Розглянуто співвідношення положень оновленого Цивільного Кодексу з положеннями нового Трудового кодексу України, зокрема, щодо конкретизації в останньому тих положень оновленого Цивільного кодексу України, які можуть бути застосовані до регулювання трудових відносин, зокрема щодо можливості стягувати з окремих категорій працівників упущену вигоду.

У статті зазначено про дискусійний характер положення Концепції оновлення Цивільного кодексу України, згідно з яким держава визнається юридичною особою.

Підтримуючи ідею про відмову від права господарського відання і права оперативного управління, звертається увага на необхідність відмови і від права постійного користування земельною ділянкою, яке передбачено у чинній редакції Земельного кодексу України. Разом з тим висловлюється теза про визначення у новому Цивільному кодексі України правових засад «здійснення» права державної та комунальної власності.

У результаті проведеного аналізу автор доходить висновку про необхідність створення механізму, який би забезпечив стабільність положень оновленого ЦК та запобігання появи в ньому положень, які не відповідають загальними засадам цивільного законодавства, суперечать його базовим положенням та не відповідають доктрині цивільного права.

Ключові слова: оновлення цивільного законодавства, приватне право, юридична особа, право господарського відання, право оперативного управління.

\section{Zub Ihor. Regarding certain aspects of the Concept of updating the Civil Code of Ukraine}

The article analyzes some provisions of the Concept of updating the Civil Code of Ukraine. First of all, it is about supporting the proposal to repeal the Commercial Code of Ukraine. At the same time, the idea of the possibility of adopting a codified legislative act along with the updated Civil Code of Ukraine (as a code of private law), which would systematize the issues of state regulation of economic activity (registration of legal entities, licensing, permitting activity, etc.) is described.

The correlation of the provisions of the updated Civil Code with the provisions of the new Labor Code of Ukraine is considered, in particular, in concretization in the latter of those provisions of the updated Civil Code of Ukraine that can be applied to labor relations, in particular, the ability to recover the lost profit from certain categories of workers.

The paper includes debatable character of the provision of the Concept of updating the Civil Code of Ukraine, according to which the state is recognized as a legal entity.

Supporting the idea of waiving the right of economic management and the right of operational management, attention is drawn to the need to waive the right of permanent use of land, which is provided in the current version of the Land Code of Ukraine. At the same time, the thesis about the definition in the new Civil Code of Ukraine of the legal principles of "exercise" of the right of state and communal property is recognized. 
As a result of the analysis, the author concludes that it is necessary to create a mechanism that would ensure the stability of the updated CC and prevent the emergence of provisions that do not meet the general principles of civil law, contradict its basic provisions and do not comply with civil law.

Key words: updating of civil legislation; private law; legal entity; the right of economic management; the right of operational management.

Одним із основних завдань, що стоїть сьогодні перед представниками приватноправових наук, $€$ забезпечення прийняття оновленого Цивільного кодексу України (далі - ЦК) на підставі Концепції його оновлення [1] (далі - Концепція). Проте варто зазначити, що оптимальною формою, в якій оновлений ЦК подаватиметься до парламенту, виступає новий ЦК. Це пояснюється, зокрема, тим, що «за необхідності суттєвого оновлення закону, коли внесення до нього змін відповідатиме або ж перевищуватиме за обсягом чинну редакцію закону, або ж зміни істотно впливатимуть на його зміст, доцільно прийняти новий закон, визнавши існуючий закон таким, що втратив чинність» [2].

Підкреслімо, що Концепція загалом виглядає як системний документ закінченого характеру, що, однак, не виключає можливості обговорення ії̈ окремих положень $з$ метою їх подальшого вдосконалення. Тим більше, що і самі члени Робочої групи з розробки Концепції «розраховують на конструктивні ініціативи правничої спільноти» $[1 ; 5]$. У зв'язку з цим вважаємо за доцільне висловити щодо окремих положень Концепції декілька зауважень та пропозицій, звертаючи увагу насамперед на вплив положень оновленого ЦК як «стрижневого акта для всіх суспільних відносин 3 приватноправовим змістом» [3], а отже, й на інші кодифікаційні акти з елементами приватного права, умовно кажучи, «тісно пов'язані» з ним.

1. Насамперед варто погодитися з тим, що прийняття оновленого ЦК має супроводжуватися скасуванням чинного Господарського кодексу України (далі - ГК) (§ 1.1. розділу I). Це пояснюється тим, що останній у його сьогоднішній редакції виглядає не лише як «дублер» ЦК, в якому тим чи іншим шляхом повторюються (перекручуються) відповідні норми ЦК, а й (що більш негативно впливає на загальне регулювання відповідних суспільних відносин), як його ідеологічний антипод. I невипадково пропозиція про скасування ГК викликала бурю емоцій у його прихильників, що проявились, зокрема, у вигляді Науково-експертного висновку до Концепції оновлення Цивільного кодексу України (далі - Висновок) [4]. Зазначимо, що під час ознайомлення 3 Висновком складається враження, що його автори недостатньо уважно ознайомилися з Концепцією, побачивши у ній лише положення про скасування чинного ГК. При цьому поза їхньою увагою залишилось інше її принципово важливе положення, за яким «водночас, як у часи підготовки проекту чинного ЦК України, так і в сучасних умовах усе вищенаведене (критика положень чинного ГК - I.3.) не спрямоване на те, щоб заперечувати важливість публічно-правових норм, які сприяють державному регулюванню економіки (податки, державна реєстрація тощо), а державна підтримка підприємництва була і залишається важливою передумовою адекватної систематизації відповідних норм» $[1 ; 76]$. Виходячи з цієї тези, вважаємо, що оптимальною відповіддю на поставлені І.В. Спасибо-Фатєєвою питання (чи будуть існувати ЦК і ГК, в якому також регулюватися цивільні відносини; чи можливо вести мову про три закони: ЦК, Торговий кодекс і публічний закон в сфері управління економікою? [5]), мало 6 стати як прийняття оновленого ЦК як кодексу приватного права, так і «публічного закону у сфері управління економікою» як кодексу публічного права, в якому мають бути систематизовані питання державного регулювання господарської діяльності (порядок реєстрації юридичних осіб, ліцензування, дозвільна діяльність, державний контроль, технічне регулювання тощо), з структурою близькою, наприклад, до структури Господарського кодексу Республіки Казахстан [6]. Тим більш, що, як вказано у Висновку, «загалом зміст ГК можна оцінити як такий, що на $2 \backslash 3 \epsilon$ публічно-правовим» [4; 16]. 
Проте у разі, якщо такий проєкт не буде розроблений, скасування чинної редакції ГК (принаймні, внесення до нього змін, якими з нього виключаються норми приватно-правового характеру) залишається необхідною умовою для прийняття оновленого ЦК, оскільки без цього позитивний ефект від його прийняття буде суттєво зменшений.

2. У § 1.4. розділу I Концепції визначається, що «скасування ГК зумовлює необхідність внесення змін до ст. 9 ЦК України, яка визначає порядок та пріоритети у застосуванні ЦК до врегулювання приватноправових відносин у сферах охорони довкілля, праці, сім'ї, підприємництва тощо» $[1 ; 8]$. Щодо цього варто зазначити, що навряд чи скасування ГК тягне за собою необхідність внесення змін до ст. 9 ЦК щодо застосування положень ЦК, зокрема, до врегулювання трудових відносин. Однак це не виключає необхідності узгодження між собою відповідних положень оновленого ЦК та нового кодифікованого законодавчого акту у сфері праці, в тому числі й щодо конкретизації у останньому тих положень ЦК, які можуть бути застосовані до регулювання трудових відносин. При цьому зазначимо, що у зареєстрованих на цей час у Верховній Раді України проєктах відповідних законодавчих актів ідея ст. 9 ЦК про застосування положень ЦК для регулювання трудових відносин, якщо вони не врегульовані самим трудовим законодавством, майже не знайшла свого відображення (застосування цивільного законодавства передбачається лише щодо відшкодування моральної шкоди, заподіяної роботодавцем працівникові). Разом з тим постають питання, які, принаймні, слід обговорити у процесі підготовці вказаних кодексів. Зокрема, йдеться про можливість визнання трудового договору нечинним з визначенням наслідків такого визнання (як це передбачено, зокрема, у Трудовому кодексі Республіки Білорусь [7]), або можливості у деяких випадках стягувати з окремих категорій працівників упущену вигоду. Зазначимо, що ні чинний Кодекс законів України про працю, ні зареєстровані проєкти такої можливості не передбачають. Тут, до речі, не можна не звернути увагу, на § 1.9. розділу II Концепції, де передбачається, що у ЦК пови- нні міститься положення про відповідальність менеджменту товариства перед його учасниками. У зв'язку з цим стає незрозумілим чи означає це, що з менеджментом товариств мають укладатися винятково цивільно-правові договори чи залишиться можливість укладати трудові договори, але з умовою про цивільно-правову відповідальність перед його учасниками (чи перед товариством). Разом з тим 3 поширенням практики укладення 3 менеджментом товариств цивільно-правових договорів виникає питання про можливість включення до таких договорів умов щодо реалізації менеджерами, наприклад, права на відпочинок, в тому числі на відпустку, чи правомірності їх підпорядкування іншим посадовим особам товариства з точки зору відповідності такого підпорядкування юридичної рівності сторін як ключової ознаки цивільних відносин. Варто також звернути увагу, що повна інкорпорація «модернізованих» положень Закону України «Про міжнародне приватне право», у оновлений ЦК, що пропонується у Концепції вимагає уточнення сфери відносин, які регулюються в ньому, оскільки частина положень чинної редакції Закону України «Про міжнародне приватне право» спрямовані на регулювання інших, ніж цивільні, відносин.

Крім цього, у Концепції корисним було 6 визначитися і з долею останнього (на даний час) кодексу Української РСР Житлового: чи він має бути замінений на новий, чи регулювання відповідних суспільних відносин має відбуватися на підставі положень оновленого ЦК (право власності на житло та його оренда), закону про соціальне житло, можливо закону про надання державного та комунального житла та деяких інших спеціальних законів без кодифікації житлового законодавства.

3. Щодо положень Концепції щодо юридичних осіб вважаємо за доцільне звернути увагу на таке. Якщо у Концепції пропонується надати вичерпний перелік організаційно-правових форм юридичних осіб ((§ 1.8. розділу II), то, на нашу думку, варто уточнити, що це має стосуватися не лише юридичних осіб приватного права, але й юридичних осіб публічного права. Крім цього, погоджуючись з необхідністю 
об'єктивізації у ЦК загальних положень щодо усіх форм юридичних осіб (§ 1.9. розділу II Концепції), звертаємо увагу на необхідність більш чіткого визначення правового положення непідприємницьких товариств (їх видів, органів управління, вимог до змісту установчих документів тощо), враховуючи, зокрема, те, що до таких товариств мають належати громадські об'єднання, політичні партії, релігійні та самоврядні організації, організації колективного управління тощо.

Водночас доволі дискусійною виглядає пропозиція про визнання держави юридичною особою, перш за все з огляду на незрозумілість практичної необхідності такої конструкції, зокрема, для майнових відносин цивільного характеру, виходячи із розуміння держави як організації політичної влади, а також складності застосування до держави відповідних положень ЦК. Наприклад, щодо створення юридичної особи, управління такою юридичною особою, можливості її припинення тощо. Це зауваження стосується також і визнання юридичними особами Автономної Республіки Крим та територіальних громад.

До речі, мабуть варто нагадати, що у проєкті ЦК 1996 року [8] передбачалось, що держава, Автономна Республіка Крим, адміністративно-територіальні утворення беруть участь у відносинах, що регулюються цивільним законодавством, у формі відповідних скарбниць (загальнодержавна, Автономної Республіки Крим, адміністративно-територіального утворення), які $\epsilon$ юридичними особами публічного права, а також у формі створюваних ними юридичних осіб, за якими закріплюється визначена частина їхнього майна.

4. Підтримуючи загалом ідею про відмову від права господарського відання і права оперативного управління (§ 3.18. розділу II Концепції) та заміну їх ринковими інструментами, варто вказати, що так само, мабуть, слід відмовиться і від права постійного користування земельною ділянкою, передбаченого у чинній редакції Земельного Кодексу України (далі - ЗК), яке має однакову природу з правом господарського відання та оперативного управління. Разом з тим потрібно зауважити, що відмова від вказаних прав не $\epsilon$ проблемою оновлення ЦК як такого, оскільки зміст вказаних прав розкривається не у ньому, а у ГК та ЗК відповідно, що підтверджує тезу, що у Концепції розглядаються питання не лише оновлення ЦК, а й питання системного оновлення всього масиву законодавства, тісно пов'язаного з цивільним законодавством. Зазначимо також, що відмова від вказаних прав має супроводжуватися визначенням у тих статтях ЦК, які регулюють державну та комунальну власність, правових засад управління таким майном, чи, як вказано у статті 326 чинного ЦК, «здійснення» права державної власності. Крім цього, зауважимо також, що відповідний процес має бути синхронізовано з процесом перетворення державних та комунальних підприємств, установ та організацій на інші види юридичних осіб, а тому він, скоріше за все, буде доволі довготривалим. До того ж слід врахувати, що частину «державних» юридичних осіб (наприклад, органи державної влади та місцевого самоврядування, військові частини тощо) навряд чи взагалі можна перетворити у «недержавні юридичні особи».

5. І останнє, на що хотілось би звернути увагу, це - необхідність створення механізму, який би забезпечив стабільність положень оновленого ЦК та запобігання появи в ньому положень, які не відповідають загальними засадам цивільного законодавства, суперечать його базовим положенням та не відповідають доктрині цивільного права.

\section{ЛITEPATУРA:}

1. Концепція оновлення Цивільного кодексу України: Київ : ТОВ «Видавничий дім «АртЕк», 2020. 128 c.

2. Правила оформлення проектів законів та основні вимоги законодавчої техніки (методичні рекомендації). Аппарат Верховної Ради України. Видання четверте, виправлене і доповнене, Київ - 2014. URL: https://zakon.rada.gov.ua/rada/show/n0002451-06?find=1\&text=\% D1\%80\%D0\%B5\%D0\%B4\%D0\%B0\%D0\%BA\%D1\%86\%D1\%96\#w1_3 .

3. Погребний С.О., Кот О.А. Оновлення Цивільного кодексу України як запорука ефективної взаємодії держави та суспільства. Вісник Національної академії правових наук 
України. Харків : Право. 1921. Том 28, № 1. 204 c. URL: http://visnyk.kh.ua/uk/journals/ visnik-naprnu-1-2021-r.

4. Науково-експертний висновок до Концепції оновлення Цивільного Кодексу України / під заг. ред. члена-кореспондента НАН В.А. Устименка. Київ: НАН України, ДУ «Інститут економіко-правових досліджень імені В.К. Мамутова НАН України», 2021, 112 с.

5. І.В. Спасибо-Фатєєва. 3 приводу концепції щодо модернізації Цивільного кодексу України (рекодифікації). URL: https://sud.ua/ru/news/blog/157375-z-privodu-kontseptsiyi-schodomodernizatsiyi-tsivilnogo-kodeksu-ukrayini-rekodifikatsiyi.

6. Господарський кодекс Республіки Казахстан: URL: https://online.zakon.kz/Document/ ?doc_id=38259854.

7. Трудовий кодекс Республіки Білорусь URL: https://трудовой-кодекс.бел/statya-23.

8. Проект Цивільного кодексу України: URL: http://w1.c1.rada.gov.ua/pls/zweb2/ webproc4_1?pf3511=12096. 